\title{
Variation in root-to-shoot translocation of cadmium and zinc among different accessions of the hyperaccumulators Thlaspi caerulescens and Thlaspi praecox
}

\author{
J. P. Xing ${ }^{1,2}$, R. F. Jiang ${ }^{1}$, D. Ueno ${ }^{3}$, J. F. Ma ${ }^{3}$, H. Schat ${ }^{4}$, S. P. McGrath ${ }^{2}$ and F. J. Zhao ${ }^{2}$ \\ ${ }^{1}$ Key Laboratory of Plant-Soil Interactions of the Ministry of Education, College of Resources and Environmental Sciences, China Agricultural University, \\ Beijing 100094, People’s Republic of China; ${ }^{2}$ Soil Science Department, Rothamsted Research, Harpenden, Hertfordshire AL5 2JQ, UK; ${ }^{3}$ Research Institute \\ for Bioresources, Okayama University, Chuo 2-20-1, Kurashiki 710-0046, Japan; ${ }^{4}$ Department of Ecology and Physiology of Plants, Faculty of Earth and Life \\ Sciences, Vrije Universiteit, De Boelelaan 1085, 1081 HV Amsterdam, the Netherlands
}

Author for correspondence

F. J. Zhao

Tel: 441582763313

Fax: 441582760981

Email: Fangiie.Zhao@bbsrc.ac.uk

Received: 16 October 2007

Accepted: 19 December 2007

\section{Summary}

- Efficient root-to-shoot translocation is a key trait of the zinc/cadmium hyperaccumulators Thlaspi caerulescens and Thlaspi praecox, but the extent of variation among different accessions and the underlying mechanisms remain unclear.

- Root-to-shoot translocation of $\mathrm{Cd}$ and $\mathrm{Zn}$ and apoplastic bypass flow were determined in 10 accessions of $T$. caerulescens and one of $T$. praecox, using radiolabels ${ }^{109} \mathrm{Cd}$ and ${ }^{65} \mathrm{Zn}$. Two contrasting accessions ( $\mathrm{Pr}$ and $\mathrm{Ga}$ ) of $T$. caerulescens were further characterized for TCHMA4 expression and metal compartmentation in roots. - Root-to-shoot translocation of ${ }^{109} \mathrm{Cd}$ and ${ }^{65} \mathrm{Zn}$ after $1 \mathrm{~d}$ exposure varied 4.4 to 5 -fold among the 11 accessions, with a significant correlation between the two metals, but no significant correlation with uptake or the apoplastic bypass flow. The $F_{2}$ progeny from a cross between accessions from Prayon, Belgium (Pr) and Ganges, France (Ga) showed a continuous phenotype pattern and transgression. There was no significant difference in the TCHMA4 expression in roots between $\mathrm{Pr}$ and $\mathrm{Ga}$. Compartmentation analysis showed a higher percentage of ${ }^{109} \mathrm{Cd}$ sequestered in the root vacuoles of $\mathrm{Ga}$ than $\mathrm{Pr}$, the former being less efficient in translocation than the latter.

- Substantial natural variation exists in the root-to-shoot translocation of $\mathrm{Cd}$ and $\mathrm{Zn}$, and root vacuolar sequestration may be an important factor related to this variation.

Key words: cadmium, compartmentation, hyperaccumulation, Thlaspi caerulescens, Thlaspi praecox, translocation, zinc.

New Phytologist (2008) 178: 315-325

(c) The Authors (2008). Journal compilation @ New Phytologist (2008)

doi: 10.1111/j.1469-8137.2008.02376.x

\section{Introduction}

Hyperaccumulation of metals or metalloids by plants involves at least three key processes: efficient absorption by roots, efficient root-to-shoot translocation and hypertolerance through internal detoxification (Baker et al., 2000; Pollard et al., 2002; Assunção et al., 2003b; McGrath \& Zhao, 2003). Thlaspi caerulescens is one of the best known examples of hyperaccumulators, being able to hyperaccumulate zinc, as well as cadmium or nickel in some accessions. The mechanisms of uptake and tolerance in this plant species have been studied intensively in recent years. Tolerance is achieved mainly through vacuolar sequestration and complexation with ligands (Küpper et al., 1999, 2004; Salt et al., 1999; Ma et al., 2005; Ueno et al., 2005). Enhanced uptake is possibly attributed to hyperexpression of metal transporter genes in T. caerulescens compared with 
nonhyperaccumulating species (Pence et al., 2000; Assunção et al., 2001; van de Mortel et al., 2006).

Although $\mathrm{Zn}$ hyperaccumulation is a species-wide constitutive property in T. caerulescens, there is substantial natural variation among different accessions in the uptake of and tolerance to $\mathrm{Zn}$, which is even more pronounced in the case of $\mathrm{Cd}$ and $\mathrm{Ni}$ (Meerts \& van Isacker, 1997; Escarré et al., 2000; Lombi et al., 2000; Assunção et al., 2003a; Roosens et al., 2003). Physiological evidence suggests that there are multiple transporters mediating the influx of $\mathrm{Zn}$ and $\mathrm{Cd}$ with different affinities for the two metals in different accessions with contrasting accumulation patterns (Lombi et al., 2001; Zhao et al., 2002). Furthermore, quantitative trait locus (QTL) analyses of segregating populations from intraspecific crosses between different $T$. caerulescens accessions have identified a number of QTLs for $\mathrm{Zn}$ and $\mathrm{Cd}$ accumulation, some of which are colocated, while the others are metal-specific (Assunção et al., 2006; Deniau et al., 2006).

The process of root-to-shoot translocation is less well understood. When compared with nonhyperaccumulating species, T. caerulescens and another $\mathrm{Zn}$ hyperaccumulator, Arabidopsis halleri, have a much higher level of expression of the $P_{1 \mathrm{~B}}$-type ATPase genes, especially TcHMA4 or AhHMA4 (Bernard et al., 2004; Hammond et al., 2006; van de Mortel et al., 2006; Talke et al., 2006). There is strong evidence that AtHMA4 mediates efflux of $\mathrm{Zn}$ and $\mathrm{Cd}$ from the xylem parenchyma cells to the xylem vessels, and therefore plays a key role in their transport from root to shoot in Arabidopsis thaliana (Mills et al., 2003, 2005; Hussain et al., 2004; Verret et al., 2004). TcHMA4 is possibly also involved in the xylem loading of $\mathrm{Zn}$ and Cd in T. caerulescens (Papoyan \& Kochian, 2004), and its high expression in roots of this plant species may explain the efficient root-to-shoot translocation. It has been reported that $A h H M A 4$ colocalizes with a major QTL for $\mathrm{Cd}$ and $\mathrm{Zn}$ tolerance in $A$. halleri measured by root elongation (Courbot et al., 2007; Willems et al., 2007). The elevated expression of AhHMA4 may serve as an efficient mechanism for improving $\mathrm{Cd}$ and $\mathrm{Zn}$ tolerance in plants under the conditions of $\mathrm{Cd} / \mathrm{Zn}$ excess by maintaining low cellular $\mathrm{Cd}^{2+}$ and $\mathrm{Zn}^{2+}$ through efflux of these ions.

Another possible reason for the efficient translocation is that hyperaccumulating plants may sequester smaller amounts of metals in roots than nonhyperaccumulating species. Lasat et al. (1998) tested this hypothesis by analysing the compartmentation of ${ }^{65} \mathrm{Zn}$ in the root tissues of T. caerulescens and of the nonhyperaccumulator Thlaspi arvense. They found that T. arvense roots retained a larger proportion of ${ }^{65} \mathrm{Zn}$ in the vacuole compartment than $T$. caerulescens, which may explain the lower translocation efficiency in the former than the latter. There is also a possibility that some $\mathrm{Zn}$ and $\mathrm{Cd}$ may enter the xylem vessels via the apoplastic pathway, although the extent of contribution by this pathway has not been determined experimentally. White et al. (2002) argued for a significant role for the apoplastic pathway in $\mathrm{Zn}$ hyperaccumulation in
T. caerulescens. Their argument is based mainly on a comparison of literature data on $\mathrm{Zn}$ influx in roots and accumulation in shoots. However, as admitted by White et al. (2002), their calculations excluded the possible contribution by low-affinity transporters, which would be more prominent in the high concentration range of external $\mathrm{Zn}$. Metal-specific accumulation patterns observed in different accessions of $T$. caerulescens also cannot be explained by a significant apoplastic pathway because of its lack of selectivity for different metals (Ernst et al., 2002).

Previous studies have alluded to the variations in the shoot-toroot ratios of $\mathrm{Zn}$ and $\mathrm{Cd}$ concentrations among different accessions of T. caerulescens (Schat et al., 2000; Assunção et al., 2003a; Roosens et al., 2003), suggesting different efficiencies of root-to-shoot translocation. However, the reasons underlying these variations are not clear. The main aim of the present study was to characterize the natural variations in the efficiencies of root-to-shoot translocation of $\mathrm{Zn}$ and $\mathrm{Cd}$ among different accessions of $T$. caerulescens and Thlaspi praecox; the latter was recently identified as a hyperaccumulator of $\mathrm{Zn}$ and $\mathrm{Cd}$ (Vogel-Mikus et al., 2005). Specifically, we investigated the relationship between the translocation efficiency of $\mathrm{Zn}$ and $\mathrm{Cd}$, and their relationship with the apoplastic bypass flow. Furthermore, the expression level of TcHMA4 and compartmentation of $\mathrm{Cd}$ in roots were compared in two accessions of T. caerulescens with contrasting translocation efficiency.

\section{Materials and Methods}

\section{Plant culture}

Ten accessions of Thlaspi caerulescens J. \& C. Presl. and one accession of Thlaspi praecox Wulfen were used. Table 1 shows the abbreviation for each accession, location and the metal status of the soil at the accession sites. Seeds were sown in plastic trays filled with fine vermiculite. After germination, seedlings were watered with a basal nutrient solution containing (in $\mu \mathrm{M}$ ) $1000 \mathrm{Ca}\left(\mathrm{NO}_{3}\right)_{2}, 1000 \mathrm{KNO}_{3}, 500 \mathrm{MgSO}_{4}, 250 \mathrm{~K}_{2} \mathrm{HPO}_{4}$, $50 \mathrm{KCl}, 10 \mathrm{H}_{3} \mathrm{BO}_{3}, 1.8 \mathrm{MnSO}_{4}, 0.2 \mathrm{Na}_{2} \mathrm{MoO}_{4}, 0.31 \mathrm{CuSO}_{4}$, $50 \mathrm{Fe}(\mathrm{III})$-EDDHA (ethylenediamine-di(o-hydroxyphenylacetic acid)), $1 \mathrm{ZnSO}_{4}$. The nutrient solution was buffered at c. $\mathrm{pH} 6.0$ with $2 \mathrm{~mm}$ MES (2-morpholinoethanesulphonic acid, $\mathrm{pH}$ adjusted with $\mathrm{KOH}$ ). All experiments were carried out in a controlled environment room with the following conditions: $12 \mathrm{~h}$ day length with a light intensity of $350 \mu \mathrm{mol}$ photons $\mathrm{m}^{-2} \mathrm{~s}^{-1}$ supplied by sodium vapour lamps, $20: 16^{\circ} \mathrm{C}$ day : night temperature, and $70: 80 \%$ day : night relative humidity.

\section{Uptake and root-to-shoot translocation of ${ }^{109} \mathrm{Cd}$} and ${ }^{65} \mathrm{Zn}$

Seedlings ( $5 \mathrm{wk}$ old) were transferred to $55-\mathrm{ml}$ plastic pots (one seedling per pot) and grown for $3 \mathrm{wk}$ in the basal 
New

Phytologist

Table 1 Location and site characteristics of different Thlaspi accessions used in the present study

\begin{tabular}{llll}
\hline Species & Accession & Abbreviation & Site characteristics \\
\hline T. caerulescens & Bizkaia, Spain & $\mathrm{Bi}$ & $\mathrm{Zn} / \mathrm{Pb}$ mine spoil \\
& Black Rock, UK & $\mathrm{Br}$ & $\mathrm{Zn} / \mathrm{Pb}$ mine spoil \\
& Clough Wood, UK & $\mathrm{Cw}$ & $\mathrm{Zn} / \mathrm{Pb}$ mine spoil \\
& Ganges, France & $\mathrm{Ga}$ & $\mathrm{Zn} / \mathrm{Pb}$ mine spoil \\
& La Calamine, Belgium & $\mathrm{Lc}$ & $\mathrm{Zn} / \mathrm{Pb}$ mine spoil \\
& Lellingen, Luxembourg & $\mathrm{Le}$ & Uncontaminated soil \\
& Monte Prinzera, Italy & $\mathrm{Mp}$ & Ultramafic soil (serpentine) \\
& Prayon, Belgium & $\mathrm{Pr}$ & Zn/Pb mine spoil \\
& Viviez, France & $\mathrm{Vi}$ & Soil impacted by Zn smelter \\
& Whitesike, UK & $\mathrm{Wh}$ & Zn/Pb mine spoil \\
T. praecox & Žerjav, Northern Slovenia & $\mathrm{Tp}$ & Soil impacted by Pb mining and smelting \\
\hline
\end{tabular}

nutrition solution, which was renewed once every $3 \mathrm{~d}$. Each of the 11 accessions was replicated in six pots. The nutrient solution was then replaced with an uptake solution containing $5 \mu \mathrm{M} \mathrm{CdSO}_{4}$ labelled with $1 \mathrm{KBq}{ }^{109} \mathrm{Cd}$ and $5 \mu \mathrm{M} \mathrm{ZnSO}_{4}$ labelled with $2 \mathrm{KBq}^{65} \mathrm{Zn}$ in the basal nutrition solution $(\mathrm{pH}$ 6.0). Nutrient solution was aerated during the uptake period. After $24 \mathrm{~h}$ uptake, seedlings were rinsed with deionized water and separated into shoots and roots, blotted dry and weighed. The radioactivities of ${ }^{109} \mathrm{Cd}$ and ${ }^{65} \mathrm{Zn}$ were determined by gamma spectroscopy (Wallac Wizard 1470, PerkinElmer, Boston, MA, USA).

An additional experiment was conducted to determine the distribution of ${ }^{109} \mathrm{Cd}$ and ${ }^{65} \mathrm{Zn}$ between roots and shoots in two accessions ( $\mathrm{Pr}$ and $\mathrm{Ga}$ ) of T. caerulescens following the initial radiolabel feeding period. Seedlings were fed with ${ }^{109} \mathrm{Cd}$ and ${ }^{65} \mathrm{Zn}$ for $24 \mathrm{~h}$ as described above. Roots were then rinsed briefly with deionized water and transferred to the same nutrient solution without ${ }^{109} \mathrm{Cd}$ and ${ }^{65} \mathrm{Zn}$ labels. Seedlings from five replicates were harvested at 1, 2, 3 and $5 \mathrm{~d}$. Radioactivities of ${ }^{109} \mathrm{Cd}$ and ${ }^{65} \mathrm{Zn}$ in roots and shoots were determined.

To investigate the genetic basis controlling the variation in $\mathrm{Cd}$ and $\mathrm{Zn}$ translocation from roots to shoots, an $F_{2}$ progeny from the cross of $\operatorname{Pr} \times \mathrm{Ga}$ of $T$. caerulescens (Zha et al., 2004) was used. One hundred and twenty $F_{2}$ seedlings and 20 each of the parental controls were precultured to $8 \mathrm{wk}$ old. Uptake and distribution of ${ }^{109} \mathrm{Cd}$ and ${ }^{65} \mathrm{Zn}$ after $24 \mathrm{~h}$ feeding were determined as described above.

\section{Apoplastic bypass flow}

The apoplastic bypass flow was quantified using the apoplastic tracer dye trisodium-8-hydroxy-1,3,6-pyrenetrisulphonic acid (PTS), following the method of Yeo et al. (1999). PTS is a water-soluble, membrane-impermeable fluorescent dye, which is transported to plant shoots via apoplastic bypass flow (Yeo et al., 1999). Seedlings of the 11 accessions were precultured as described above. Seedlings ( $8 \mathrm{wk}$ old) were placed in 55-ml pots with the uptake solution containing $30 \mathrm{mg} \mathrm{PTS}^{-1}$ and the basal nutrition solution including $5 \mu \mathrm{M} \mathrm{ZnSO}_{4}$ and $5 \mu \mathrm{MdSO}_{4}(\mathrm{pH}$ 6.0). The control solution was identical to the uptake solution, but without PTS. Each treatment was replicated in four pots for each Thlaspi accession. After $24 \mathrm{~h}$, seedlings were separated into shoots and roots, rinsed thoroughly with deionized water, blotted dry and weighed. The shoots were cut into fine pieces and extracted with $10 \mathrm{ml}$ deionized water in a water bath at $90^{\circ} \mathrm{C}$ for $2 \mathrm{~h}$. The fluorescence of the extracts was measured with a luminescence spectrometer (PerkinElmer Luminescence Spectrometer LS 50B) at $\lambda_{\text {excitation }} 403 \mathrm{~nm}$ and $\lambda_{\text {emission }} 510 \mathrm{~nm}$. The mean fluorescence value of the control for each accession was subtracted from the treatment with PTS. The data were expressed as the fluorescence intensity at $\lambda_{\text {emission }} 510 \mathrm{~nm} \mathrm{~g}^{-1}$ shoot fresh weight.

\section{Expression of TCHMA4}

The expression levels of TcHMA4 in roots and shoots of the accessions $\mathrm{Ga}$ and $\operatorname{Pr}$ were quantified using real-time RT-PCR. Seedlings ( $20 \mathrm{~d}$ old) were transferred to $1.2-1$ pots (four plants per pot) and treated with $10 \mu \mathrm{M}$ or $100 \mu \mathrm{M} \mathrm{Zn}$, or $10 \mu \mathrm{M} \mathrm{Zn}+5 \mu \mathrm{M} \mathrm{Cd}$, for $8 \mathrm{~d}$. Each treatment was replicated four times. Nutrient solutions were aerated continuously and renewed every $3 \mathrm{~d}$. Total RNA was extracted from the shoot and root tissues using an RNeasy Plant Mini Kit (Qiagen, Tokyo, Japan), then converted to cDNA using the SuperScript FirstStrand Synthesis System for RT-PCR (Invitrogen, Carlsbad, CA, USA). For quantitative determination of mRNA by real-time RT-PCR, the cDNAs for TcHMA4 were amplified by PCR (ABI PRISM 7500 real-time PCR system; Applied Biosystems, Foster City, CA, USA) using SYBR Premix Ex Taq (Takara Bio Inc., Otsu, Japan) with the primers $5^{\prime}$-tcgcttctataagaagacttagg- $3^{\prime}$ and $5^{\prime}$-catcgaccacaattccatcaatag- $3^{\prime}$ (GenBank no. AJ567384) $\left(45 \mathrm{~s}\right.$ at $95^{\circ} \mathrm{C}$, followed by 40 cycles of $15 \mathrm{~s}$ at $95^{\circ} \mathrm{C}, 30 \mathrm{~s}$ at $62^{\circ} \mathrm{C}$ and $45 \mathrm{~s}$ at $72^{\circ} \mathrm{C}$ ). Actin was used as an internal control. The primers for actin were $5^{\prime}$-gagactttcaatgccctgc- $3^{\prime}$ and 

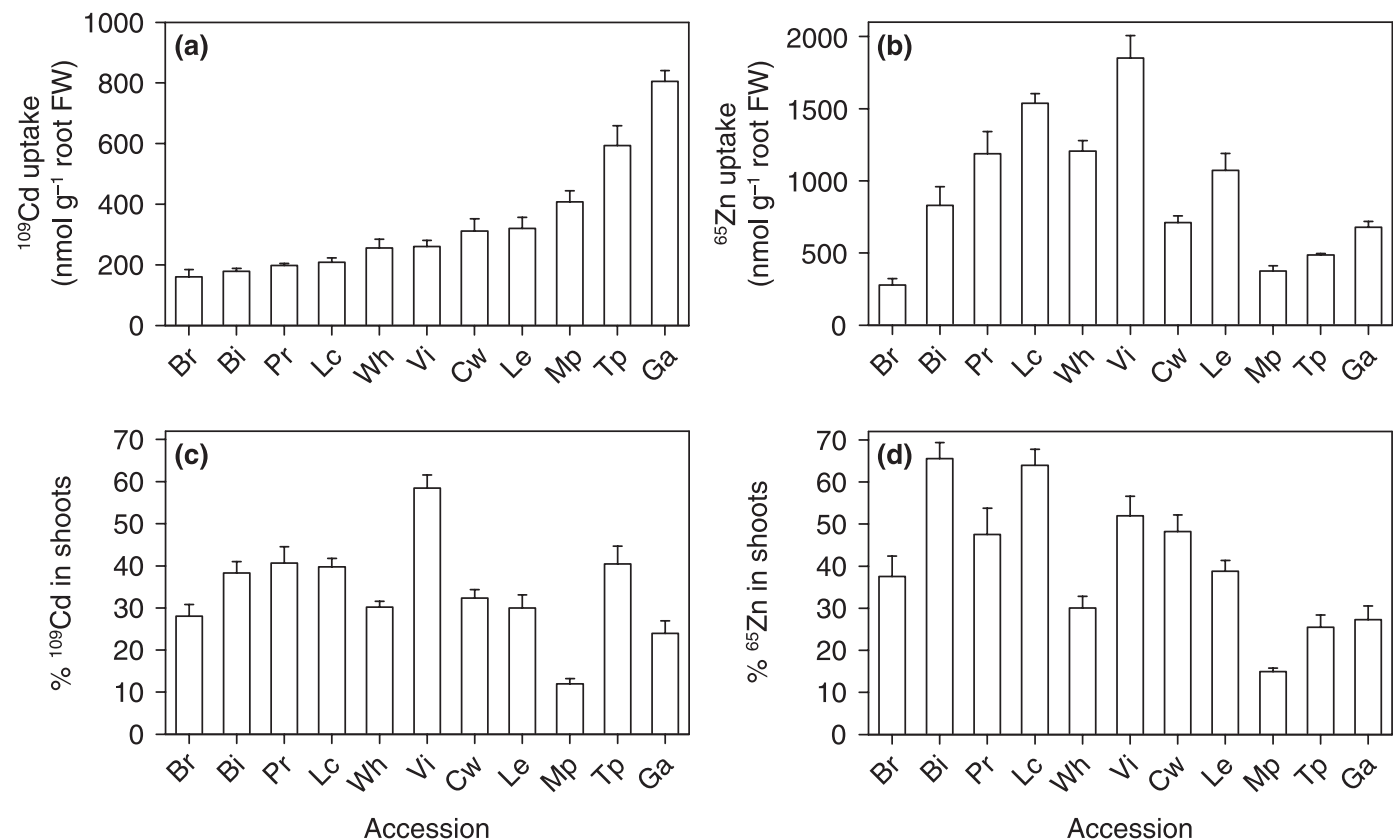

Fig. 1 Variation in the uptake of (a) ${ }^{109} \mathrm{Cd}$; (b) ${ }^{65} \mathrm{Zn}$ and the percentage of (c) ${ }^{109} \mathrm{Cd}$; (d) ${ }^{65} \mathrm{Zn}$ translocated to shoots among 11 accessions of Thlaspi caerulescens and Thlaspi praecox. Data are mean $+\mathrm{SE}(n=6)$.

$5^{\prime}$-ccatctccagagtcgagcaca-3'. The quantitative PCR data for TcHMA4 were normalized with the expression level of actin.

\section{${ }^{109} \mathrm{Cd}$ compartmentation in roots}

A short-term ${ }^{109} \mathrm{Cd}$ efflux experiment was conducted to estimate $\mathrm{Cd}$ compartmentation in roots of the $\mathrm{Pr}$ and $\mathrm{Ga}$ accessions of $T$. caerulescens. The method was similar to that used for ${ }^{65} \mathrm{Zn}$ by Lasat et al. (1998). Seedlings (8 wk old) were incubated in separate $55-\mathrm{ml}$ pots with an uptake solution containing $0.5 \mathrm{~mm} \mathrm{CaCl}_{2}, 2 \mathrm{~mm}$ MES ( $\mathrm{pH}$ 6.0) and $5 \mu \mathrm{M}$ $\mathrm{CdSO}_{4}$ labelled with $5 \mathrm{KBq}{ }^{109} \mathrm{Cd}$. After uptake for $24 \mathrm{~h}$, roots of intact seedlings were rinsed briefly with deionized water, wiped gently with tissue, and placed in an aerated efflux solution, which was identical with the uptake solution except without ${ }^{109} \mathrm{Cd}$. At 14 different intervals from 2 to $360 \mathrm{~min}$, a 2.5- $\mathrm{ml}$ aliquot of the efflux solution was taken for the determination of ${ }^{109} \mathrm{Cd}$ radioactivity, and the efflux solution was renewed. During the efflux experiment, plants were placed under shade to reduce transpiration. At the end of the experiment, seedlings were rinsed with deionized water, separated into shoots and roots, blotted dry, weighed, and counted for ${ }^{109} \mathrm{Cd}$ radioactivity. The ${ }^{109} \mathrm{Cd}$ efflux data were fitted successively to three linear equations to estimate the pool size and efflux half-life corresponding to the cell wall, cytoplasm and vacuole compartments, as described by Lasat et al. (1998).

\section{Statistical analysis}

ANOVA was used to test the significance of difference among accessions or treatments.

\section{Results}

Uptake and root-to-shoot translocation of ${ }^{109} \mathrm{Cd}$ and ${ }^{65} \mathrm{Zn}$ in 11 Thlaspi accessions

After seedlings were exposed to radiolabelled $\mathrm{Cd}$ and $\mathrm{Zn}$ (5 $\mu$ m each) for $24 \mathrm{~h}$, uptake of ${ }^{109} \mathrm{Cd}$ and ${ }^{65} \mathrm{Zn}$, expressed on the basis of root FW, varied 5.0- and 6.7-fold, respectively, among the 11 Thlaspi accessions $(P<0.001$; Fig. 1a,b). Consistent with previous reports (Lombi et al., 2000; Roosens et al., 2003), the Ga accession of T. caerulescens had the highest Cd uptake, while the $\mathrm{Vi}$ accession had the highest $\mathrm{Zn}$ uptake. The T. praecox accession from northern Slovenia also had a high Cd uptake, confirming its $\mathrm{Cd}$ hyperaccumulating ability observed in the field specimens (Vogel-Mikus et al., 2005). Interestingly, there was no significant correlation $(r=0.35, n=11, P=0.29)$ between $\mathrm{Cd}$ and $\mathrm{Zn}$ uptake (Fig. 2a).

Within $24 \mathrm{~h}, 12-59$ and $15-66 \%$ of ${ }^{109} \mathrm{Cd}$ and ${ }^{65} \mathrm{Zn}$, respectively, had been transported to shoots (Fig. 1c,d). The variation in translocation efficiency was 4.9- and 4.4-fold for $\mathrm{Cd}$ and $\mathrm{Zn}$, respectively, among the 11 accessions $(P<0.001)$. Unlike uptake, the translocation efficiency of $\mathrm{Cd}$ and $\mathrm{Zn}$ correlated significantly $(r=0.64, n=11, P<0.05$; Fig. 2b). 
New

Phytologist
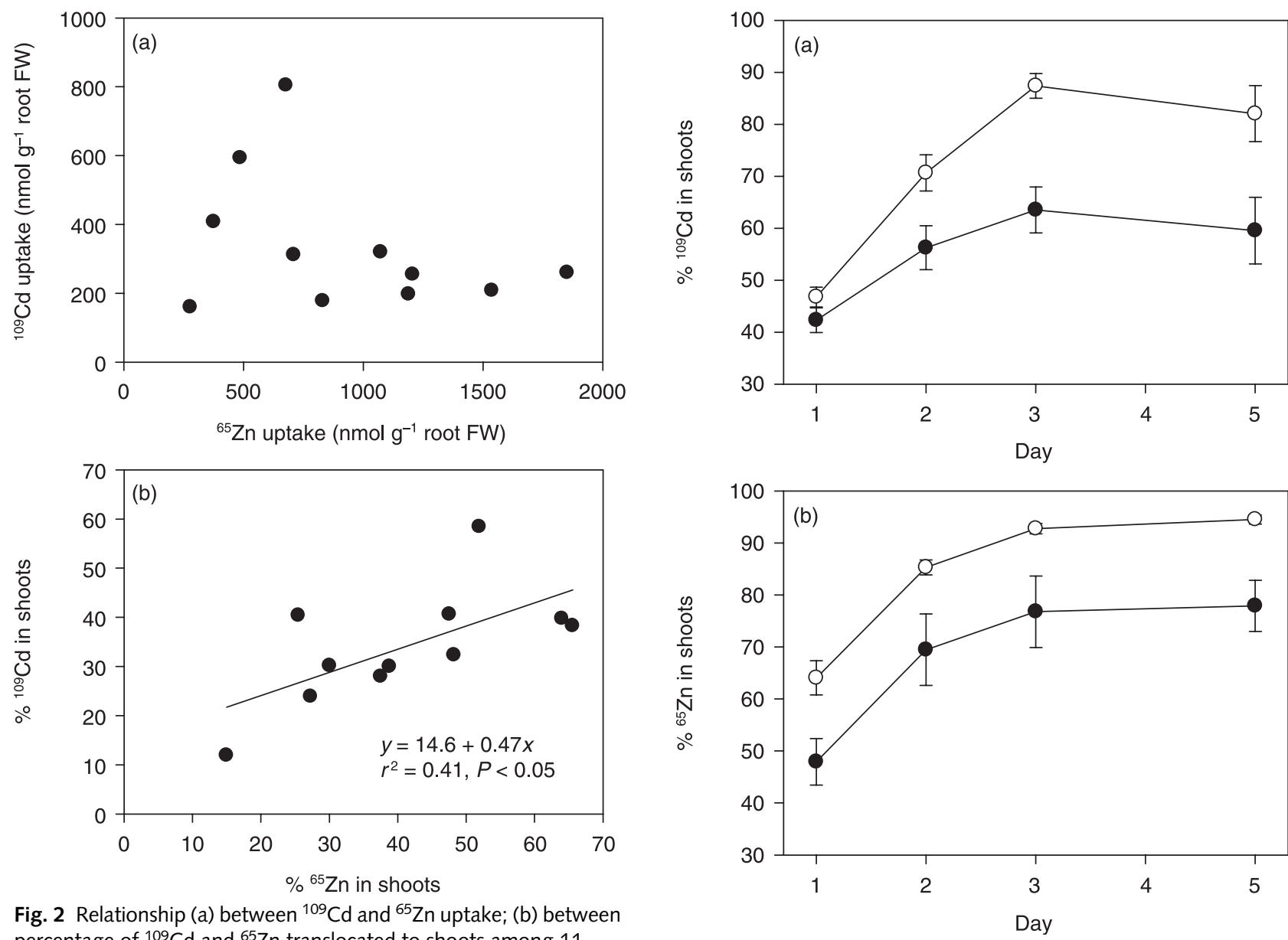

Fig. 2 Relationship (a) between ${ }^{109} \mathrm{Cd}$ and ${ }^{65} \mathrm{Zn}$ uptake; (b) between percentage of ${ }^{109} \mathrm{Cd}$ and ${ }^{65} \mathrm{Zn}$ translocated to shoots among 11 accessions of Thlaspi caerulescens and Thlaspi praecox.

Neither the Cd nor the $\mathrm{Zn}$ translocation efficiency correlated significantly with the root : shoot biomass ratio (for $\mathrm{Cd}$ : $r=0.15, n=11, P=0.66$; for $\mathrm{Zn}: r=0.50, n=11, P=0.11$; data not shown). It is conceivable that low translocation efficiency may be a result of rapid root uptake owing to saturation of the translocation machinery; in this case there should be a negative correlation between uptake and translocation efficiency. However, there was no significant correlation $(r=0.31$, $n=11, P=0.35)$ between Cd translocation efficiency and $\mathrm{Cd}$ uptake by roots (data not shown). In the case of $\mathrm{Zn}$, its translocation efficiency appeared to increase with uptake, although the correlation also did not reach a significant level ( $r=0.57, n=11, P=0.06$; data not shown).

To investigate the translocation efficiency of $\mathrm{Cd}$ and $\mathrm{Zn}$ over a longer period, the $\mathrm{Ga}$ and $\operatorname{Pr}$ accessions were exposed to radiolabelled $\mathrm{Cd}$ and $\mathrm{Zn}(5 \mu \mathrm{M}$ each) for $1 \mathrm{~d}$, followed by $4 \mathrm{~d}$ in the normal nutrient solution without ${ }^{109} \mathrm{Cd}$ and ${ }^{65} \mathrm{Zn}$. Figure 3 shows that the percentage of both ${ }^{109} \mathrm{Cd}$ and ${ }^{65} \mathrm{Zn}$ in shoots increased with time up to $3 \mathrm{~d}$ after feeding. Similarly to the data presented in Fig. 1, the Pr accession had a higher translocation efficiency for both metals than the Ga accession

Fig. 3 Percentage of (a) ${ }^{109} \mathrm{Cd}$; (b) ${ }^{65} \mathrm{Zn}$ translocated to shoots in the $\mathrm{Ga}$ (closed circles) and $\operatorname{Pr}$ (open circles) accessions of Thlaspi caerulescens following ${ }^{109} \mathrm{Cd}$ and ${ }^{65} \mathrm{Zn}$ exposure for $1 \mathrm{~d}$. Data are mean \pm SE $(n=5)$.

$(P<0.001)$. For both $\mathrm{Cd}$ and $\mathrm{Zn}$ translocation efficiency, there were no significant interactions between accession and time.

\section{Apoplastic bypass flow}

The PTS concentration in shoots varied 4.9-fold among the 11 accessions $(P=0.011$; Fig. 4a), showing a strong correlation with the root : shoot biomass ratio $(r=0.91, n=11, P<0.001$; Fig. $4 \mathrm{~b})$. However, there was no significant correlation between PTS concentration and $\mathrm{Cd}$ or $\mathrm{Zn}$ translocation efficiency (for Cd: $r=0.02, n=11, P=0.95$; for $\mathrm{Zn}: r=0.27, n=11$, $P=0.42$; Fig. 4c,d).

Root-to-shoot translocation of ${ }^{109} \mathrm{Cd}$ and ${ }^{65} \mathrm{Zn}$ in $F_{2}$ progeny from the $\operatorname{Pr} \times \mathrm{Ga}$ cross

A previous study (Zha et al., 2004) reported a cosegregation analysis of $\mathrm{Cd}$ and $\mathrm{Zn}$ accumulation in the $F_{2}$ progeny from 

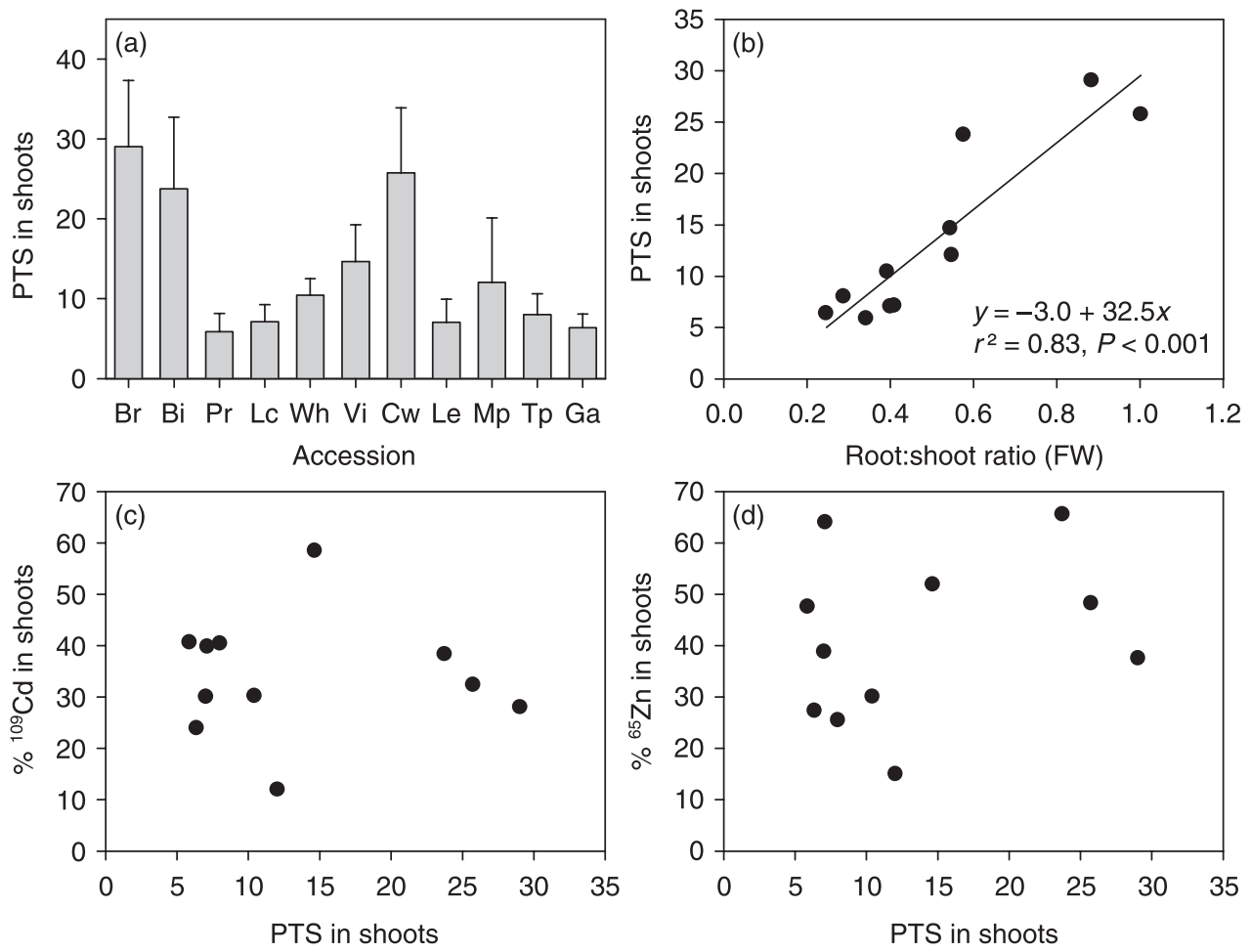

Fig. 4 Variation in the apoplastic bypass flow as measured by the fluorescence of trisodium-8-hydroxy-1,3,6-pyrenetrisulphonic acid (PTS) in shoots among 11 accessions of Thlaspi caerulescens and Thlaspi praecox (a); correlation between PTS in shoots and root : shoot biomass ratio (b); correlation between PTS in shoots and percentage of ${ }^{109} \mathrm{Cd}(\mathrm{c})$ or ${ }^{65} \mathrm{Zn}(\mathrm{d})$ translocated to shoots. PTS is expressed as fluorescence intensity $\mathrm{g}^{-1}$ shoot FW. Data in (a) are mean + SE $(n=4)$.

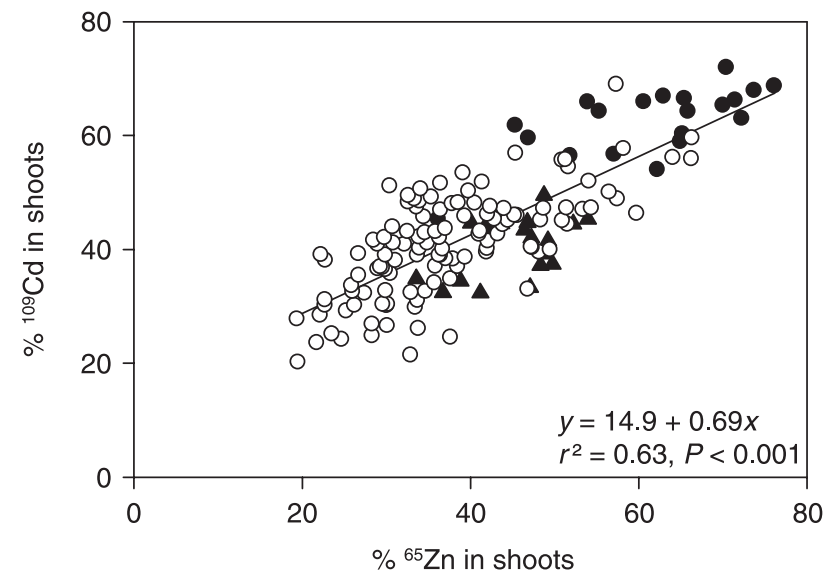

Fig. 5 Relationship between percentage of ${ }^{109} \mathrm{Cd}$ and ${ }^{65} \mathrm{Zn}$ translocated to shoots in parental controls and $F_{2}$ progeny of the $\mathrm{Pr} \times \mathrm{Ga}$ cross of Thlaspi caerulescens. Triangles, Ga; closed circles, Pr; open circles, $F_{2}$.

the $\operatorname{Pr} \times \mathrm{Ga}$ and $\mathrm{Ga} \times \operatorname{Pr}$ crosses, using both soil and hydroponic experiments with a relatively long $(40-45 \mathrm{~d})$ exposure to $\mathrm{Cd}$ and $\mathrm{Zn}$. In the present study, we analysed the segregation patterns of $\mathrm{Cd}$ and $\mathrm{Zn}$ translocation in the $F_{2}$ progeny from the $\operatorname{Pr} \times \mathrm{Ga}$ cross and the parental controls, after plants were given radiolabelled $\mathrm{Cd}$ and $\mathrm{Zn}(5 \mu \mathrm{M}$ each) for $24 \mathrm{~h}$. Similar to the results with 11 accessions described above (Fig. 2b), there was a strong correlation $(r=0.79, n=160$, $P<0.001)$ between the percentage of ${ }^{109} \mathrm{Cd}$ and ${ }^{65} \mathrm{Zn}$ transported to shoots in the parental and $F_{2}$ plants. A single linear regression described the data well for both parental controls and $F_{2}$ plants (Fig. 5). Figure 6 shows the phenotypic distributions in the parental controls and $F_{2}$ plants. The $\operatorname{Pr}$ accession had a higher root-to-shoot translocation efficiency for both $\mathrm{Cd}$ and $\mathrm{Zn}$ than the Ga accession, and the phenotypes of the two overlapped slightly. The distribution patterns in the $F_{2}$ were continuous, but biased toward the phenotype range of $\mathrm{Ga}$. There was evidence of transgression for both $\mathrm{Cd}$ and $\mathrm{Zn}$ translocation efficiency beyond the lowest parental range, but not above the highest parental range.

\section{Expression of TCHMA4}

Real-time RT-PCR was used to quantify the transcript abundance of $T c H M A 4$, a prime candidate gene implicated in the root-to-shoot transport of $\mathrm{Zn}$ and $\mathrm{Cd}$ in T. caerulescens (Bernard et al., 2004; Papoyan \& Kochian, 2004). Figure 7 shows the relative levels of transcript abundance in shoot and root tissues of the Ga and $\mathrm{Pr}$ accessions grown with different concentrations of $\mathrm{Zn}$ and $\mathrm{Cd}$. The transcript level in roots was 
New

Phytologist
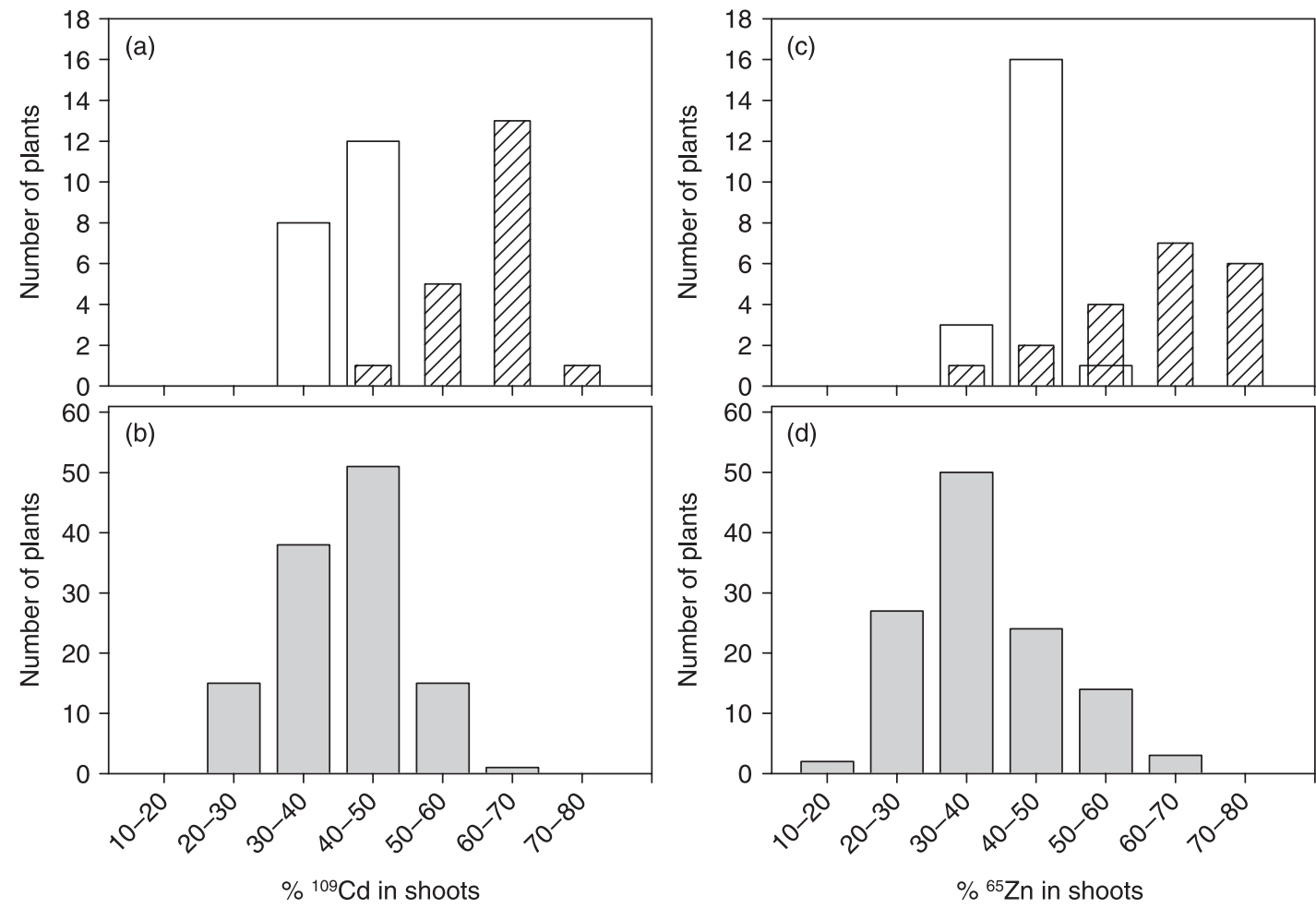

Fig. 6 Phenotype distribution of percentage of ${ }^{109} \mathrm{Cd}$ and ${ }^{65} \mathrm{Zn}$ translocated to shoots in parental controls $(\mathrm{a}, \mathrm{c})$ and $F_{2}$ progeny $(\mathrm{b}, \mathrm{d})$ of the $\operatorname{Pr} \times \mathrm{Ga}$ cross of Thlaspi caerulescens. ${ }^{109} \mathrm{Cd}(\mathrm{a}, \mathrm{b})$ and ${ }^{65} \mathrm{Zn}(\mathrm{c}, \mathrm{d})$. Hatched bars, Pr; open bars, Ga; grey bars, $F_{2}$.

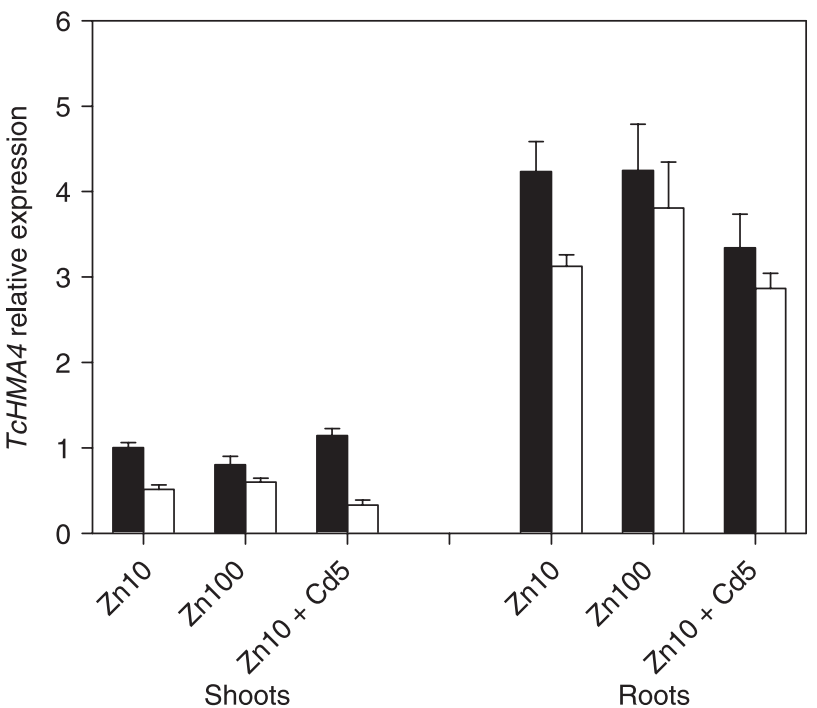

Fig. 7 Relative expression level of TcHMA4 in roots and shoots of the $\mathrm{Ga}$ (closed bars) and $\operatorname{Pr}$ (open bars) accessions of Thlaspi caerulescens as influenced by $\mathrm{Zn}$ and $\mathrm{Cd}$ treatments. TcHMA4 transcript abundance of root and shoot tissues from different treatments were compared with that of the Ga shoot tissue from the $10 \mu \mathrm{M} Z n$ treatment. Data are mean + SE $(n=4)$. three to nine times higher than that in shoots of either accession. Two-way ANOva involving accession and $\mathrm{Zn} / \mathrm{Cd}$ treatments was performed on the root or shoot TcHMA4 data. There was a near-significant $(P=0.051)$ difference in the transcript level in roots between the $\mathrm{Ga}$ and $\mathrm{Pr}$ accessions, with Ga having approx. 20\% higher transcript abundance than Pr. The transcript level in shoots was $c$. twofold higher in Ga than in $\operatorname{Pr}(P<0.001)$. The different $\mathrm{Zn}$ and $\mathrm{Cd}$ treatments had no significant effect on the expression of TcHMA4.

\section{${ }^{109} \mathrm{Cd}$ compartmentation in roots}

A possible explanation for the difference in the $\mathrm{Cd}$ and $\mathrm{Zn}$ translocation efficiency among different accessions may lie in the compartmentation of the metals in the root cells. Cadmium compartmentation in the root cells of the Ga and $\operatorname{Pr}$ accessions was investigated using the method of short-term ${ }^{109} \mathrm{Cd}$ efflux. Similarly to previous studies on ${ }^{65} \mathrm{Zn}$ efflux from T. caerulescens roots (Lasat et al., 1998), the time-dependent kinetics of ${ }^{109} \mathrm{Cd}$ efflux from $\mathrm{Ga}$ and Pr roots could be resolved into three linear phases (Fig. 8), representing Cd efflux from cell walls $(0-15 \mathrm{~min})$, cytoplasm (30-60 min) and vacuoles (180-360 min). The amounts of ${ }^{109} \mathrm{Cd}$ in the three compartments and the rate of efflux (efflux half-life $t_{1 / 2}$ ), estimated from the three linear regression lines, are shown in Table 2. After exposure to ${ }^{109} \mathrm{Cd}$ for $1 \mathrm{~d}$, Ga roots accumulated more 
Table $2{ }^{109} \mathrm{Cd}$ compartmentation and half-life $\left(t_{1 / 2}\right)$ for ${ }^{109} \mathrm{Cd}$ efflux from different root cell compartments of the Ga and $\mathrm{Pr}$ accessions of Thlaspi caerulescens

\begin{tabular}{llccc}
\hline Accession & & Cell wall & Cytoplasm & Vacuole \\
\hline $\mathrm{Ga}$ & Amount of ${ }^{109} \mathrm{Cd}\left(\mathrm{nmol} \mathrm{g}{ }^{-1} \mathrm{FW}\right)$ & $145.5 \pm 31.0$ & $87.1 \pm 14.6$ & $659.8 \pm 34.1$ \\
& Percentage distribution of ${ }^{109} \mathrm{Cd}$ & $16.2 \pm 3.2$ & $9.6 \pm 1.2$ & $74.2 \pm 3.1$ \\
& Efflux half-life $t_{1 / 2}(\mathrm{~min})$ & $2.4 \pm 0.4$ & $25.9 \pm 3.8$ & $2306 \pm 231.0$ \\
$\operatorname{Pr}$ & Amount of ${ }^{109} \mathrm{Cd}\left(\mathrm{nmol} \mathrm{g}{ }^{-1} \mathrm{FW}\right)$ & $83.8 \pm 2.2$ & $26.6 \pm 2.8$ & $149.0 \pm 10.8$ \\
& Percentage distribution of ${ }^{109} \mathrm{Cd}$ & $32.6 \pm 1.1$ & $10.3 \pm 1.0$ & $57.1 \pm 1.6$ \\
& Efflux half-life $t_{1 / 2}(\mathrm{~min})$ & $3.3 \pm 0.6$ & $27.5 \pm 2.1$ & $2332 \pm 360.9$ \\
\hline
\end{tabular}

Values are mean \pm SE.
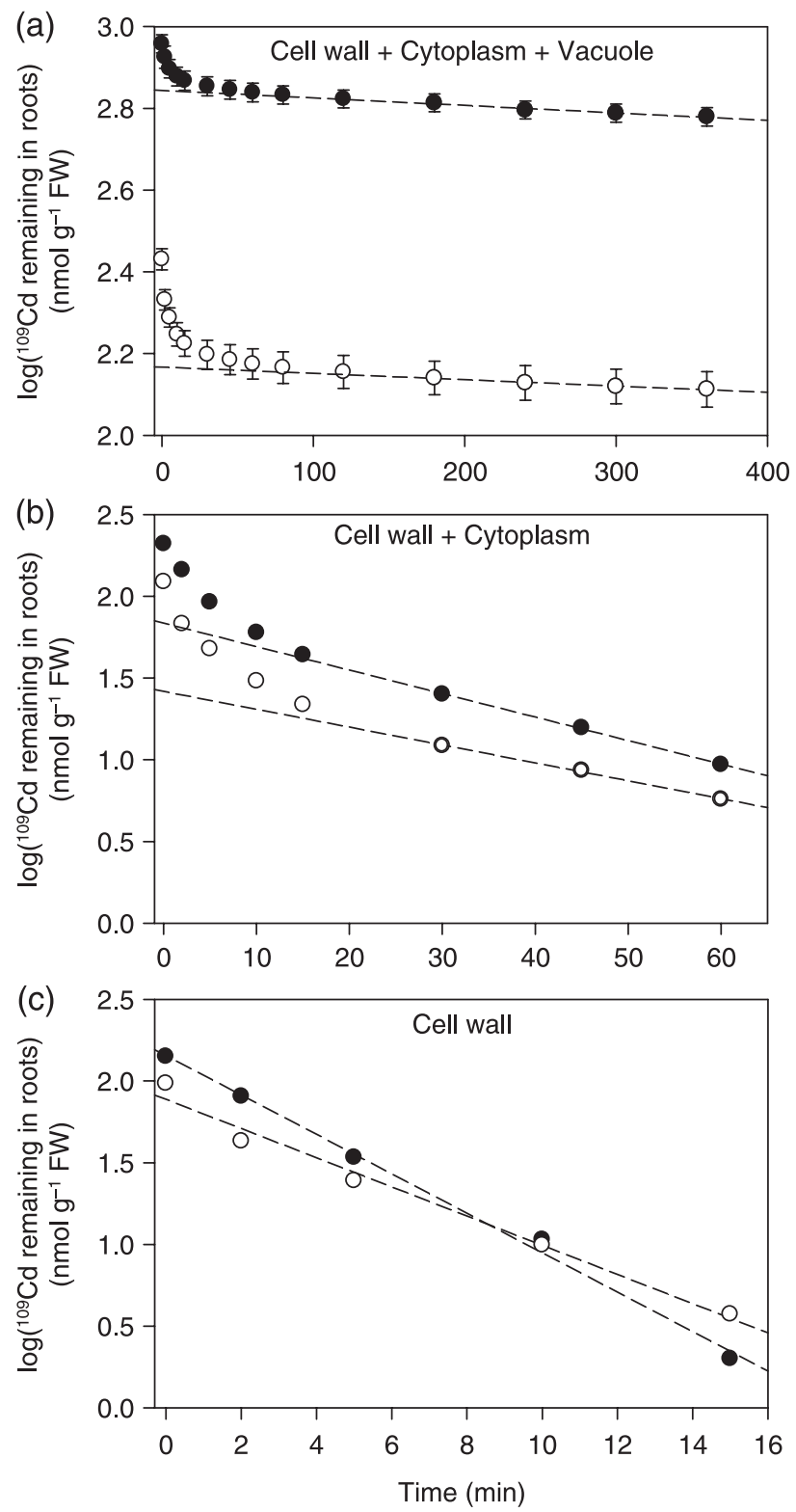

Fig. 8 Short-term efflux of ${ }^{109} \mathrm{Cd}$ from roots of the Ga (closed circles) and $\operatorname{Pr}$ (open circles) accessions of Thlaspi caerulescens. The ${ }^{109} \mathrm{Cd}$ efflux data were resolved into three linear curves representing cell wall, cytoplasm and vacuoles according to Lasat et al. (1998). Data points in (a) are mean \pm SE $(n=5)$.
${ }^{109} \mathrm{Cd}$ than Pr roots, with 1.7-, 3.3- and 4.4-fold larger amounts of ${ }^{109} \mathrm{Cd}$ in the root cell walls, cytoplasm and vacuoles, respectively, than those of Pr roots. Proportionally more ${ }^{109} \mathrm{Cd}$ was in the vacuoles of Ga roots (74\%) than in those of Pr roots (57\%). Similar proportions (approx. $10 \%$ ) of root ${ }^{109} \mathrm{Cd}$ were found in the cytoplasm in both $\mathrm{Ga}$ and $\mathrm{Pr}$ roots, whereas the latter had a higher percentage in the cell walls than the former. The half-time for ${ }^{109} \mathrm{Cd}$ efflux from the cell walls, cytoplasm and vacuoles was similar between Ga and Pr.

\section{Discussion}

The results from the present study, using radiolabelling and short-term $(1 \mathrm{~d})$ exposure to relatively low levels of $\mathrm{Cd}$ and $\mathrm{Zn}$, show large variations in the uptake of $\mathrm{Cd}$ and $\mathrm{Zn}$ among 10 accessions of $T$. caerulescens and one accession of T. praecox (Fig. 1). There was no significant correlation between uptake of the two metals (Fig. 2), supporting the hypothesis that multiple transport systems are involved in the uptake of $\mathrm{Cd}$ and $\mathrm{Zn}$ by T. caerulescens (Lombi et al., 2001; Zhao et al., 2002; Zha et al., 2004). These results corroborate and extend previous investigations using fewer accessions (two to four) and longer exposure time (weeks) (Lombi et al., 2000; Assunção et al., 2003a; Zha et al., 2004). By contrast, Roosens et al. (2003) reported a significant correlation between $\mathrm{Zn}$ and Cd concentrations in shoots of seven accessions of T. caerulescens after exposure to the two metals for $14 \mathrm{~d}$. Metal concentration in shoots after a long exposure period is a measure of accumulation resulting from both uptake and root-to-shoot translocation, both of which are likely to be under regulation by the internal metal status (Papoyan et al., 2007), whereas the method used in our study is a better measure of root uptake per se.

The focus of the present study was on the root-to-shoot translocation of $\mathrm{Cd}$ and $\mathrm{Zn}$, which is an important process of metal hyperaccumulation, yet still poorly understood. The percentages of $\mathrm{Cd}$ and $\mathrm{Zn}$ transported to shoot within $24 \mathrm{~h}$ exposure varied widely among the 11 accessions examined (Fig. 1). Several interesting observations emerged from the present work. First, the translocation efficiency did not correlate with uptake for either metal, suggesting independent variation in uptake and translocation among different accessions 
of Thlaspi. This is consistent with the observation made by Schat et al. (2000) with three accessions of T. caerulescens. Second, there was a positive correlation between the translocation efficiency of $\mathrm{Cd}$ and $\mathrm{Zn}$ (Figs 2,5), suggesting the possibility of a common transport mechanism from roots to shoots for the two metals. This correlation was significant not only in the 11 accessions tested, but also in the $F_{2}$ progeny from the $\operatorname{Pr} \times \mathrm{Ga}$ cross, indicating a genetic correlation between the translocation efficiency of the two metals. Third, the translocation efficiency did not correlate with the apoplastic bypass flow measured with a membrane-impermeable fluorescence dye (Fig. 4). Previously, White et al. (2002) argued for a significant role of apoplastic pathway in the xylem loading of $\mathrm{Zn}$ in T. caerulescens. This hypothesis is not supported by the data shown in Fig. 4, which suggest that the variation among accessions in $\mathrm{Cd}$ and $\mathrm{Zn}$ translocation is not controlled by the apoplastic pathway. Recently, van der Mortel et al. (2006) reported the presence of two layers of endodermis in the root tissues of $T$. caerulescens, as well as enhanced expression of lignin/suberin biosynthesis genes compared with that in roots of $A$. thaliana. Their results strengthen the argument for a dominant role of the symplastic pathway in the transport of $\mathrm{Cd}$ and $\mathrm{Zn}$ to xylem.

To investigate possible reasons accounting for the variation in translocation efficiency among accessions, we chose two accessions (Ga and Pr) for further characterization. These two accessions differed significantly not only in uptake, but also in the efficiency of root-to-shoot transport of $\mathrm{Cd}$ and $\mathrm{Zn}$. Accession Ga had the highest uptake of Cd (Fig. 1); its extraordinary ability to accumulate $\mathrm{Cd}$ has been reported before (Lombi et al., 2000; Assunção et al., 2003a; Roosens et al., 2003). However, the translocation efficiency for both $\mathrm{Cd}$ and $\mathrm{Zn}$ was rather low in Ga. In comparison, accession Pr had a consistently higher translocation efficiency for both metals (Figs 1, 3). In the $F_{2}$ progeny from the $\operatorname{Pr} \times \mathrm{Ga}$ cross, the phenotype of Cd and $\mathrm{Zn}$ translocation to shoots exhibited a continuous pattern (Fig. 6). There was also evidence of transgression at the low end of the phenotype range. These results suggest a multilocus model controlling the variation in efficiency of metal translocation, with the trait-enhancing alleles originating from both $\operatorname{Pr}$ and Ga. The lack of transgression toward the high end of the phenotype range (Fig. 6) may be because of saturation of the translocation capacity, or other unknown causes.

One of the key steps in transport from roots to shoots is loading of metals into the xylem vessels in the stelar region of roots. HMA4, a metal-transporting $\mathrm{P}_{1 \mathrm{~B}}$-type ATPase, has been shown to play a key role in the root-to-shoot transport of $\mathrm{Zn}$ and $\mathrm{Cd}$ in $A$. thaliana, probably acting as an efflux pump located on the plasma membranes of xylem parenchyma cells, and delivering $\mathrm{Zn}^{2+}$ and $\mathrm{Cd}^{2+}$ to the xylem vessels (Mills et al., 2003; Hussain et al., 2004; Verret et al., 2004; Mills et al., 2005). A role in loading $\mathrm{Zn}^{2+}$ and $\mathrm{Cd}^{2+}$ into the xylem has also been implicated for TcHMA4 in T. caerulescens (Papoyan \& Kochian, 2004). We therefore investigated whether expression of TcHMA4 could account for the difference between Ga and $\mathrm{Pr}$ in the translocation efficiency of $\mathrm{Zn}$ and $\mathrm{Cd}$. Similarly to other studies on T. caerulescens (Bernard et al., 2004; Papoyan \& Kochian, 2004), TcHMA4 was expressed more in roots than in shoots (Fig. 7). The less efficient Ga accession had a somewhat higher expression level in roots than $\mathrm{Pr}$, although the difference did not quite reach the significance level. Similarly, Bernard et al. (2004) found no significant difference in TcHMA4 transcript abundance among three accessions of T. caerulescens, including the accessions from $\mathrm{Pr}$ and St Félix-dePallières, which is near Ga. Therefore it is unlikely that the difference between $\operatorname{Pr}$ and Ga in the root-to-shoot translocation of $\mathrm{Cd}$ and $\mathrm{Zn}$ is attributable to different expression levels of TcHMA4. We also found that exposure to different $\mathrm{Zn}$ $(10$ or $100 \mu \mathrm{M})$ or $\mathrm{Cd}(0$ or $5 \mu \mathrm{M})$ treatments for $8 \mathrm{~d}$ did not significantly affect $T c H M A 4$ expression (Fig. 7). Bernard et al. (2004) showed a weak but statistically insignificant induction of TcHMA4 expression by Cd. In roots of $A$. halleri, the transcript level of $A h H M A 4$ showed little response to different Zn or Cd treatments (Talke et al., 2006). By contrast, Papoyan \& Kochian (2004) reported that TcHMA4 expression in the root of the Pr accession was significantly induced by both $\mathrm{Zn}$ deficiency and exposure to high $\mathrm{Zn}$ or Cd levels.

Sequestration of metals in root vacuoles could decrease their availability for translocation to shoots, as has been shown by Lasat et al. (1998), who compared the compartmentation of ${ }^{65} \mathrm{Zn}$ in the root tissues of T. caerulescens and of the nonhyperaccumulator T. arvense. Similarly, Yang et al. (2006) found that the nonhyperaccumulating ecotype of Sedum alfredii retained 2.7-fold more $\mathrm{Zn}$ in root vacuoles than the hyperaccumulating ecotype of the same species. We compared ${ }^{109} \mathrm{Cd}$ compartmentation in the root tissues of $\mathrm{Pr}$ and Ga. Although $\mathrm{Ga}$ had higher concentrations of ${ }^{109} \mathrm{Cd}$ in all three root compartments because of a higher rate of uptake, proportionally more ${ }^{109} \mathrm{Cd}$ was stored in the vacuoles than in the Pr accession (Table 2). The difference in vacuolar sequestration may explain the difference between the two accessions in $\mathrm{Cd}$ translocation efficiency. It remains to be investigated whether the activity of tonoplast transporters for $\mathrm{Cd}$ differs between the two accessions.

In conclusion, this study has revealed a large variation in the root-to-shoot translocation of $\mathrm{Cd}$ and $\mathrm{Zn}$ among different accessions of Thlaspi, which was independent of the variation in root uptake. These accessions are valuable materials for dissecting the traits responsible for $\mathrm{Zn}$ and $\mathrm{Cd}$ hyperaccumulation, especially translocation. The efficiency of root-to-shoot translocation was not related to apoplastic bypass flow among the 11 Thlaspi accessions examined. In the two accessions of T. caerulescens chosen for further characterization, difference in $\mathrm{Zn}$ and $\mathrm{Cd}$ translocation was not correlated with the expression level of TcHMA4 in roots. The accession with a higher translocation efficiency stored proportionally less $\mathrm{Cd}$ in root vacuoles, suggesting that vacuolar sequestration may play a role in controlling the root-to-shoot translocation of metals. 


\section{Acknowledgements}

Jianping Xing was supported by the Changjiang Scholars Program and the Innovative Research Team in University Scheme (IRT0511). We thank Sarah Dunham for technical assistance, Paula Pongrac for providing Thlaspi praecox seeds and Dr Jing-Jiang Zhou for the use of the fluorescence spectrometer. Rothamsted Research receives grant-aided support from the UK Biotechnology and Biological Sciences Research Council. This work was also partially supported by a Grantin-Aid for Exploratory Research from the Ministry of Education, Culture, Sports, Science and Technology of Japan (no. 19658027) to J.F.M.

\section{References}

Assunção AGL, Bookum WM, Nelissen HJM, Vooijs R, Schat H, Ernst WHO. 2003a. Differential metal-specific tolerance and accumulation patterns among Thlaspi caerulescens populations originating from different soil types. New Phytologist 159: 411-419.

Assunção AGL, Martins PD, De Folter S, Vooijs R, Schat H, Aarts MGM. 2001. Elevated expression of metal transporter genes in three accessions of the metal hyperaccumulator Thlaspi caerulescens. Plant, Cell \& Environment 24: 217-226.

Assunção AGL, Pieper B, Vromans J, Lindhout P, Aarts MGM, Schat H. 2006. Construction of a genetic linkage map of Thlaspi caerulescens and quantitative trait loci analysis of zinc accumulation. New Phytologist 170: 21-32.

Assunção AGL, Schat H, Aarts MGM. 2003b. Thlaspi caerulescens, an attractive model species to study heavy metal hyperaccumulation in plants. New Phytologist 159: 351-360.

Baker AJM, McGrath SP, Reeves RD, Smith JAC. 2000. Metal hyperaccumulator plants: a review of the ecology and physiology of a biochemical resource for phytoremediation of metal-polluted soils. In: Terry N, Bañuelos G, eds. Phytoremediation of contaminated soil and water. Boca Raton, FL, USA: Lewis Publishers, 85-107.

Bernard C, Roosens N, Czernic P, Lebrun M, Verbruggen N. 2004. A novel CPx-ATPase from the cadmium hyperaccumulator Thlaspi caerulescens. FEBS Letters 569: 140-148.

Courbot M, Willems G, Motte P, Arvidsson S, Roosens N, SaumitouLaprade P, Verbruggen N. 2007. A major quantitative trait locus for cadmium tolerance in Arabidopsis halleri colocalizes with HMA4, a gene encoding a heavy metal ATPase. Plant Physiology 144: 1052-1065.

Deniau AX, Pieper B, Ten Bookum WM, Lindhout P, Aarts MGM, Schat H. 2006. QTL analysis of cadmium and zinc accumulation in the heavy metal hyperaccumulator Thlaspi caerulescens. Theoretical and Applied Genetics 113: 907-920.

Ernst WHO, Assuncao AGL, Verkleij JAC, Schat H. 2002. How important is apoplastic zinc xylem loading in Thlaspi caerulescens? New Phytologist 155: 4-5.

Escarré J, Lefebvre C, Gruber W, Leblanc M, Lepart J, Riviere Y, Delay B. 2000. Zinc and cadmium hyperaccumulation by Thlaspi caerulescens from metalliferous and nonmetalliferous sites in the Mediterranean area: implications for phytoremediation. New Phytologist 145: 429-437.

Hammond JP, Bowen HC, White PJ, Mills V, Pyke KA, Baker AJM, Whiting SN, May ST, Broadley MR. 2006. A comparison of the Thlaspi caerulescens and Thlaspi arvense shoot transcriptomes. New Phytologist 170: $239-260$.

Hussain D, Haydon MJ, Wang Y, Wong E, Sherson SM, Young J, Camakaris J, Harper JF, Cobbett CS. 2004. P-type ATPase heavy metal transporters with roles in essential zinc homeostasis in Arabidopsis. Plant Cell 16: 1327-1339.
Küpper H, Mijovilovich A, Meyer-Klaucke W, Kroneck PMH. 2004. Tissue- and age-dependent differences in the complexation of cadmium and zinc in the cadmium/zinc hyperaccumulator Thlaspi caerulescens (Ganges ecotype) revealed by X-ray absorption spectroscopy. Plant Physiology 134: 748-757.

Küpper H, Zhao FJ, McGrath SP. 1999. Cellular compartmentation of zinc in leaves of the hyperaccumulator Thlaspi caerulescens. Plant Physiology 119: 305-311.

Lasat MM, Baker AJM, Kochian LV. 1998. Altered Zn compartmentation in the root symplasm and stimulated $\mathrm{Zn}$ absorption into the leaf as mechanisms involved in $\mathrm{Zn}$ hyperaccumulation in Thlaspi caerulescens. Plant Physiology 118: 875-883.

Lombi E, Zhao FJ, Dunham SJ, McGrath SP. 2000. Cadmium accumulation in populations of Thlaspi caerulescens and Thlaspi goesingense. New Phytologist 145: 11-20.

Lombi E, Zhao FJ, McGrath SP, Young SD, Sacchi GA. 2001. Physiological evidence for a high-affinity cadmium transporter highly expressed in a Thlaspi caerulescens ecotype. New Phytologist 149: 53-60.

Ma JF, Ueno D, Zhao FJ, McGrath SP. 2005. Subcellular localisation of $\mathrm{Cd}$ and $\mathrm{Zn}$ in the leaves of a Cd-hyperaccumulating ecotype of Thlaspi caerulescens. Planta 220: 731-736.

McGrath SP, Zhao FJ. 2003. Phytoextraction of metals and metalloids from contaminated soils. Current Opinion in Biotechnology 14: 277-282.

Meerts P, van Isacker N. 1997. Heavy metal tolerance and accumulation in metallicolous and non-metallicolous populations of Thlaspi caerulescens from continental Europe. Plant Ecology 133: 221-231.

Mills RF, Francini A, da Rocha P, Baccarini PJ, Aylett M, Krijger GC, Williams LE. 2005. The plant P-1B-type ATPase AtHMA4 transports $\mathrm{Zn}$ and $\mathrm{Cd}$ and plays a role in detoxification of transition metals supplied at elevated levels. FEBS Letters 579: 783-791.

Mills RF, Krijger GC, Baccarini PJ, Hall JL, Williams LE. 2003. Functional expression of AtHMA4, a P-1B-type ATPase of the $\mathrm{Zn} / \mathrm{Co} / \mathrm{Cd} / \mathrm{Pb}$ subclass. Plant Journal 35: 164-176.

van de Mortel JE, Villanueva LA, Schat H, Kwekkeboom J, Coughlan S, Moerland PD, van Themaat EVL, Koornneef M, Aarts MGM. 2006.

Large expression differences in genes for iron and zinc homeostasis, stress response, and lignin biosynthesis distinguish roots of Arabidopsis thaliana and the related metal hyperaccumulator Thlaspi caerulescens. Plant Physiology 142: 1127-1147.

Papoyan A, Kochian LV. 2004. Identification of Thlaspi caerulescens genes that may be involved in heavy metal hyperaccumulation and tolerance. Characterization of a novel heavy metal transporting ATPase. Plant Physiology 136: 3814-3823.

Papoyan A, Pineros M, Kochian LV. 2007. Plant $\mathrm{Cd}^{2+}$ and $\mathrm{Zn}^{2+}$ status effects on root and shoot heavy metal accumulation in Thlaspi caerulescens. New Phytologist 175: 51-58.

Pence NS, Larsen PB, Ebbs SD, Letham DLD, Lasat MM, Garvin DF, Eide D, Kochian LV. 2000. The molecular physiology of heavy metal transport in the $\mathrm{Zn} / \mathrm{Cd}$ hyperaccumulator Thlaspi caerulescens. Proceedings of the National Academy of Sciences, USA 97: 4956-4960.

Pollard AJ, Powell KD, Harper FA, Smith JAC. 2002. The genetic basis of metal hyperaccumulation in plants. Critical Reviews in Plant Sciences 21: 539-566.

Roosens N, Verbruggen N, Meerts P, Ximenez-Embun P, Smith JAC. 2003. Natural variation in cadmium tolerance and its relationship to metal hyperaccumulation for seven populations of Thlaspi caerulescens from western Europe. Plant, Cell \& Environment 26: 1657-1672.

Salt DE, Prince RC, Baker AJM, Raskin I, Pickering IJ. 1999. Zinc ligands in the metal hyperaccumulator Thlaspi caerulescens as determined using X-ray absorption spectroscopy. Environmental Science \& Technology 33: $713-717$.

Schat H, Llugany M, Bernhard R. 2000. Metal-specific patterns of tolerance, uptake, and transport of heavy metals in hyperaccumulating and nonhyperaccumulating metallophytes. In: Terry N, Bañuelos G, eds. 
New

Phytoremediation of contaminated soil and water. Boca Raton, FL, USA: Lewis Publishers, 171-188.

Talke IN, Hanikenne M, Kramer U. 2006. Zinc-dependent global transcriptional control, transcriptional deregulation, and higher gene copy number for genes in metal homeostasis of the hyperaccumulator Arabidopsis halleri. Plant Physiology 142: 148-167.

Ueno D, Ma JF, Iwashita T, Zhao FJ, McGrath SP. 2005. Identification of the form of $\mathrm{Cd}$ in the leaves of a superior $\mathrm{Cd}$-accumulating ecotype of Thlaspi caerulescens using ${ }^{113} \mathrm{Cd}-\mathrm{NMR}$. Planta 221: 928-936.

Verret F, Gravot A, Auroy P, Leonhardt N, David P, Nussaume L, Vavasseur A, Richaud P. 2004. Overexpression of AtHMA4 enhances root-to-shoot translocation of zinc and cadmium and plant metal tolerance. FEBS Letters 576: 306-312.

Vogel-Mikus K, Drobne D, Regvar M. 2005. Zn, Cd and Pb accumulation and arbuscular mycorrhizal colonisation of pennycress Thlaspi praecox Wulf. (Brassicaceae) from the vicinity of a lead mine and smelter in Slovenia. Environmental Pollution 133: 233-242.

White PJ, Whiting SN, Baker AJM, Broadley MR. 2002. Does zinc move apoplastically to the xylem in roots of Thlaspi caerulescens? New Phytologist 153: 201-207.
Willems G, Dräger DB, Courbot M, Gode C, Verbruggen N, Saumitou-Laprade P. 2007. The genetic basis of zinc tolerance in the metallophyte Arabidopsis halleri ssp. halleri (Brassicaceae): an analysis of quantitative trait loci. Genetics 176: 659-674.

Yang X, Li TQ, Yang JC, He ZL, Lu LL, Meng FH. 2006. Zinc compartmentation in root, transport into xylem, and absorption into leaf cells in the hyperaccumulating species of Sedum alfredii Hance. Planta 224: 185-195.

Yeo AR, Flowers SA, Rao G, Welfare K, Senanayake N, Flowers TJ. 1999. Silicon reduces sodium uptake in rice (Oryza sativa L.) in saline conditions and this is accounted for by a reduction in the transpirational bypass flow. Plant, Cell \& Environment 22: 559-565.

Zha HG, Jiang RF, Zhao FJ, Vooijs R, Schat H, Barker JHA, McGrath SP. 2004. Co-segregation analysis of cadmium and zinc accumulation in Thlaspi caerulescens interecotypic crosses. New Phytologist 163: 299-312.

Zhao FJ, Hamon RE, Lombi E, McLaughlin MJ, McGrath SP. 2002. Characteristics of cadmium uptake in two contrasting ecotypes of the hyperaccumulator Thlaspi caerulescens. Journal of Experimental Botany 53: $535-543$.

\section{About New Phytologist}

- New Phytologist is owned by a non-profit-making charitable trust dedicated to the promotion of plant science, facilitating projects from symposia to open access for our Tansley reviews. Complete information is available at www.newphytologist.org.

- Regular papers, Letters, Research reviews, Rapid reports and both Modelling/Theory and Methods papers are encouraged. We are committed to rapid processing, from online submission through to publication 'as-ready' via OnlineEarly - our average submission to decision time is just 28 days. Online-only colour is free, and essential print colour costs will be met if necessary. We also provide 25 offprints as well as a PDF for each article.

- For online summaries and ToC alerts, go to the website and click on 'Journal online'. You can take out a personal subscription to the journal for a fraction of the institutional price. Rates start at $£ 135$ in Europe/\$251 in the USA \& Canada for the online edition (click on 'Subscribe' at the website).

- If you have any questions, do get in touch with Central Office (newphytol@lancaster.ac.uk; tel +44 1524 594691) or, for a local contact in North America, the US Office (newphytol@ornl.gov; tel +1 865576 5261). 